
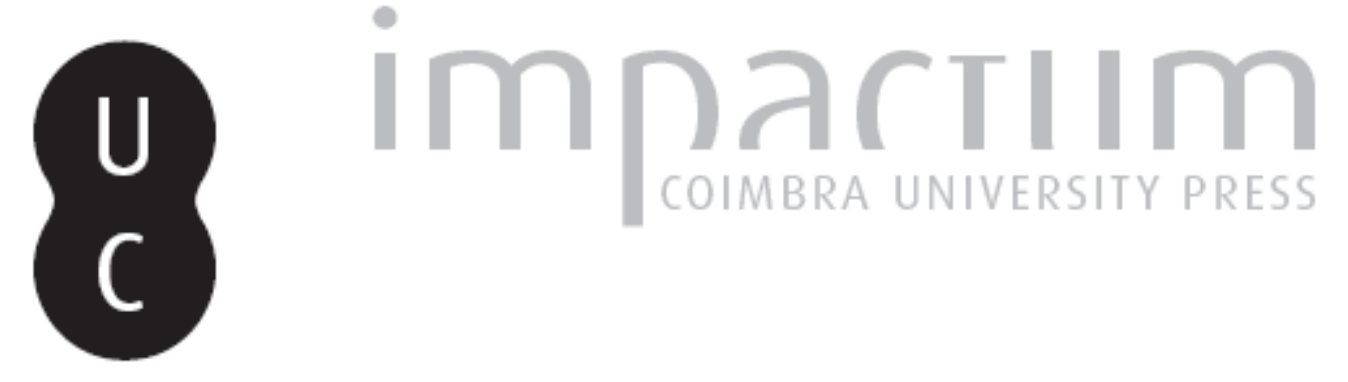

\title{
Linkages and performance comparison among Eastern Europe stock markets
}

Autor(es): $\quad$ Fonseca, José Soares da

Publicado por: Imprensa da Universidade de Coimbra

URL persistente:

URl:http://hdl.handle.net/10316.2/34611

DOI:

DOI:http://dx.doi.org/10.14195/2183-203X_39_4

Accessed : $\quad$ 26-Apr-2023 10:44:41

A navegação consulta e descarregamento dos títulos inseridos nas Bibliotecas Digitais UC Digitalis, UC Pombalina e UC Impactum, pressupõem a aceitação plena e sem reservas dos Termos e Condições de Uso destas Bibliotecas Digitais, disponíveis em https://digitalis.uc.pt/pt-pt/termos.

Conforme exposto nos referidos Termos e Condições de Uso, o descarregamento de títulos de acesso restrito requer uma licença válida de autorização devendo o utilizador aceder ao(s) documento(s) a partir de um endereço de IP da instituição detentora da supramencionada licença.

Ao utilizador é apenas permitido o descarregamento para uso pessoal, pelo que o emprego do(s) título(s) descarregado(s) para outro fim, designadamente comercial, carece de autorização do respetivo autor ou editor da obra.

Na medida em que todas as obras da UC Digitalis se encontram protegidas pelo Código do Direito de Autor e Direitos Conexos e demais legislação aplicável, toda a cópia, parcial ou total, deste documento, nos casos em que é legalmente admitida, deverá conter ou fazer-se acompanhar por este aviso.

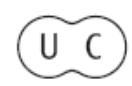




\section{N ○ TASEC O NómICAs}

DOCTOR-NURSE TEAMS, INCENTIVES AND BEHAVIOR

AIDAISABEL TAVARES

DANIEL MURTA

JOÃO SOUSA ANDRADE/ ADELAIDE DUARTE/ MARTA SIMÕES

JOSÉ SOARES DA FONSECA
THE SILENCE AT THE STANDS: AGONY IN THE PORTUGUESE MARKET FOR TAXIS

A QUANTILE REGRESSION ANALYSIS OF GROWTH AND CONVERGENCE IN THE EU: POTENTIAL IMPLICATIONS FOR PORTUGAL

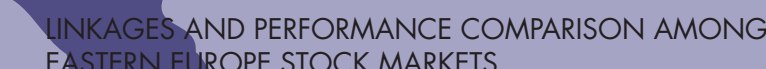
EASTERN EUROPE STOCK MARKETS

4

$\Leftrightarrow$

$\circ$

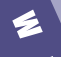

$\bullet$

$\checkmark$

$\omega$

$\theta$

i.

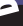
430

○

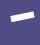

$n$

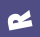

II

$=$

-

$=$

$\theta$

4

a

$a$

-

$E$

-

$=$

$\boldsymbol{\odot}$

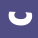

w

w

$\theta$

u

$\theta$

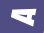

a 


\section{Linkages and Performance Comparison among Eastern Europe Stock Markets}

José Soares da Fonseca Faculdade de Economia da Universidade de Coimbra and GEMF

\section{abstract}

This article studies the linkages among the stock markets of Bulgaria, Czech Republic, Estonia, Hungary, Poland, Romania, Russia, Serbia, Slovenia and Ukraine. The empirical analysis begins with the estimation of a regional market model, whose beta parameters depend on predetermined information variables. Those parameters support the calculation of time-varying Treynor ratios used on a comparative performance analysis. A Vector Auto Regressive Model (VAR) is used to estimate the performance causality within this group of markets. The VAR model results provide evidence that there is reciprocal performance across the majority of the selected stock markets.

JEL Classification: F36, G15 
The empirical analysis of the present article evaluates the linkages between the Eastern Europe stock markets of Bulgaria, Czech Republic, Estonia, Hungary, Poland, Romania, Russia, Serbia, Slovenia and Ukraine. All the markets belong to former socialist economies, whose stock market activity is relatively recent, and which are classified as emerging markets (Czech Republic, Hungary, Poland, Russia) and frontier markets (Bulgaria, Estonia, Romania, Serbia, Slovenia, and Ukraine), by the Morgan Stanley Capital International (MSCl) classification. The differences between those economies during the period under analysis is an additional challenge to study the linkages between their stock markets. In fact this group includes Estonia and Slovenia, which are both members of the European Union and of the Euro area, Bulgaria, Czech Republic, Hungary, Poland and Romania, which are members of the European Union but not of Euro area, and Russia, Serbia and Ukraine, which are not members of the European Union.

The procedure used to evaluate the linkages between these markets begins with the estimation of regional market models. The parameters of the regional market models support the calculation of time-varying Treynor ratios, which are performance measures, and also can provide information on the market prices of risk, if their values are in close proximity, according to the arguments presented by Adcock (2007). The market model approach to financial integration analysis is strongly supported by financial integration theory, since the seminal article of Solnik (1973) who proposed the first asset pricing model in a perfectly integrated financial market. Further developments were made by Harvey (1991), who analysed the dependence of the world price of risk on macroeconomic and financial variables, and by Bekaert and Harvey (1995), who extended Harvey's study, to include the possibility of regime shifts which cause changes on the models parameters.

The market model estimations in the present article use a time-varying betas approach, to take into consideration the possibility of regime shifts. The major part of the articles on the market model, published during the sixties and the seventies, were based on constant betas. However, the issue of betas variability is present in literature since the market-timing procedure proposed by Treynor and Mazuy (1966) to evaluate the betas response to changes in the market conditions. The limits of the explanatory power of constant betas were subject to further analysis by Fama and French (1992), which showed that they depend on firms and macroeconomic variables, and later by Jagannathan and Wang (1996), who showed that are unable to explain satisfactorily the average return across different assets. Emerging and frontier stock markets are subject to permanent changes in their assets liquidity, and market capitalization. These changing conditions are natural sources of beta variability, which will be taken into consideration in the present article.

The time-varying betas approach used here is based on a recent contribution to this problem, given by Adcock et al. (2012), who proposed the inclusion of predetermined information variables to capture beta variability. This procedure is based on the assumption that assets returns are unconditionally distributed as an extended quadratic form of the predetermined information variables. An additional advantage of this method is that it can include the most traditional answer to the beta variability problem, the market-timing procedure, as one of its particular cases. The estimation of the market model with time-varying betas supports the calculation of Treynor ratios, which are both performance measures and essential information on the integration between these markets. The linkages between the Treynor ratios of these markets are estimated by a Vector Auto Regressive Model.

This article is organized as follows. Section 2 presents the theoretical background of the regional market model estimated, and of the comparative performance analysis based on Treynor ratios. Section 3 presents the database and the results of the market models estimation. Section 4 presents the Treynor ratios calculation and the estimation of the Vector Auto Regressive Model, together with Granger and Sims causality tests. The conclusion finishes the article. 
The stock market model is a relation between the excess expected return of an individual asset or portfolio, and the excess return of a market portfolio. Similarly, an international, or regional, market model is the relation between a domestic market portfolio and an international (worldwide or regional) portfolio, and takes the following representation:

$$
E_{t}\left(R_{i}\right)-r_{f, t}=\alpha_{i}+\beta_{i, t}\left(E_{t}\left(R_{W}\right)-r_{f, t}\right)
$$

where $E_{t}\left(R_{i}\right)$ is the expected return of the domestic portfolio on period t, $E_{t}\left(R_{W}\right)$ is the expected return of the international portfolio, during the same period, $r_{f t}$ is the international risk free shortterm interest rate, $\alpha_{i}$ is the autonomous return component of the domestic market (not dependent on the international factor), and $\beta_{i, t}$ is the sensitivity of the domestic market expected excess return of the international stock market.

The estimation of the international market model in the present article uses two predetermined information variables to explain the beta coefficients variability: the international market current excess return (which is the market-timing variable), and the lagged excess return of the domestic market. The time-varying beta parameters are defined as follows, according to this predetermined information variable approach:

$$
\beta_{i, t}=\beta_{i, 0}+\beta_{i, 1}\left(R_{W, t}-r_{f, t}\right)+\beta_{i, 2}\left(R_{i, t-1}-r_{f, t-1}\right)
$$

where $\beta_{i, 0}$ is the beta constant term, $\beta_{i, 1}$ is the beta term related to market timing effect, i.e., the beta change caused by the international index excess return, and $\beta_{i, 2}$ is the beta term related to the lagged dependent variable, $R_{i, t-1}{ }^{-} r_{f, t}$

The Treynor ratios, proposed by Treynor (1965) to evaluate funds performance, are given by the following relation between excess return and beta parameters:

$$
T_{i, t}=\frac{E\left(R_{i, t}\right)-r_{f, t}}{\beta_{i, t}}
$$

The original Treynor ratios were proposed to be calculated with constant betas. In the present article, by the contrary, they are calculated using time-varying betas, dependent on the predetermined information variables. The Treynor ratios differences between a group of countries are caused by their autonomous return, represented by the constant $\alpha$ in the market model. By consequence, if all the countries in the group are perfectly integrated in the international market their autonomous return components are zero, and thus, their Treynor ratios are equal. According to Adcock (2007), the market price of risk is a performance measure whose value is common to all the assets in a market. This argument can be extended to the international level, when performance measures, here represented by the Treynor ratios have the same value across different markets. In that case, the Treynor ratio value is equal to the international market price of risk, and those markets are perfectly integrated.

\section{Estimation of time-varying beta market models}

The empirical research of the present article uses MSCI (Morgan Stanley Capital International) Indexes of the stock markets under study, expressed in Euros. The database consists of daily 
data, covering the period between the $1^{\text {st }}$ January 2009 and the $31^{\text {st }}$ December 2012, and comprising 1043 observations of each national index. The original series were transformed into new series whose values were 100 , at $1^{\text {st }}$ January 2009, for all the indexes. The European Overnight Interest Average (EONIA) was used as a proxy of the short-term interest rate. There are two main reasons to choose this proxy of the risk-free asset. The first reason is the absence of a money market common to this group of countries. The second reason is that EONIA is a variable suitable to represent the short-term opportunity cost of investing in these Eastern Europe countries, from the point of view of an international investor. An equally weighted portfolio, composed by the domestic indexes of the database, was created to serve as regional index in this empirical analysis. The equally weighted portfolio offers several advantages over other international indexes, such as the Emerging Markets Index and the Frontier Markets Index, supplied by MSCl. In fact, none of the two $\mathrm{MSCl}$ indexes covers the entire group of stock markets under analysis. Furthermore, the equally weighted index constructed in the present article precludes the estimation bias caused by differences of market capitalization.

The testable version of the model estimated in this empirical analysis is the following:

$R_{i, t}-r_{f, t}=\alpha_{i}+\beta_{i, t}\left(R_{W, t}-r_{f, t}\right)+\varepsilon_{i, t}$

where $R_{i, t}{ }^{-} r_{f, t}$ is the ex post excess current return of the country i stock index, $R_{W, t}{ }^{-r_{f, t}}$ is the excess return of the regional index, and $\varepsilon_{i, t}$ is the error term.

The market model was estimated under the assumption that the residual series, $\varepsilon_{i, t}$, follow $\operatorname{GARCH}(\mathrm{p}, \mathrm{q})$ models, according to which their conditional volatility, $h_{t}^{2}$, takes the following general representation:

$h_{t}^{2}=\phi_{0}+\sum_{i=1}^{q} \phi_{i} \varepsilon_{t-i}^{2}+\sum_{j=1}^{p} \theta_{j} h_{t-j}^{2}$

This procedure corrects the autoregressive heteroskedasticity put in evidence by preliminary estimations.

Table I, Panel A, presents the results of the estimations of the beta coefficients of the Euro area market model and the GARCH processes. The standardized residuals (i.e. the residuals divided by the squared root of the conditional variance) were tested for autocorrelation, by a Ljung-Box test, and for ARCH (Autoregressive Conditional Heteroskedasticity) by an $\mathrm{F}$ test on the coefficients of the following auto regressive model:

$\varepsilon_{i, t}^{* 2}=a+\sum_{j=1}^{l} b_{j} \varepsilon_{i, t-j}^{* 2}+\mu_{i, t}$

where $\varepsilon_{i, t}^{*}=\varepsilon_{i, t} / \sqrt{h_{i, t}}$ is the standardized residual of the estimation of the market model. Both the Ljung-Box test and the ARCH test were carried out for a maximum of 24 lags, with a span of 4 lags. The results of the tests for residual autocorrelation, represented in Table I, Panel B, show that the residuals of the estimations are not auto correlated. Table I, Panel C, shows the results of the tests of ARCH effects on the squared standardized residuals. According to these results, the GARCH models estimated entirely eliminate the ARCH effects from the regressions residuals. The estimations results show that $\operatorname{GARCH}(1,1)$ is suitable to explain the residual volatility in the estimations of the market model of almost all these domestic indexes, the only exception being Romania, which required a $\operatorname{GARCH}(2,1)$. 

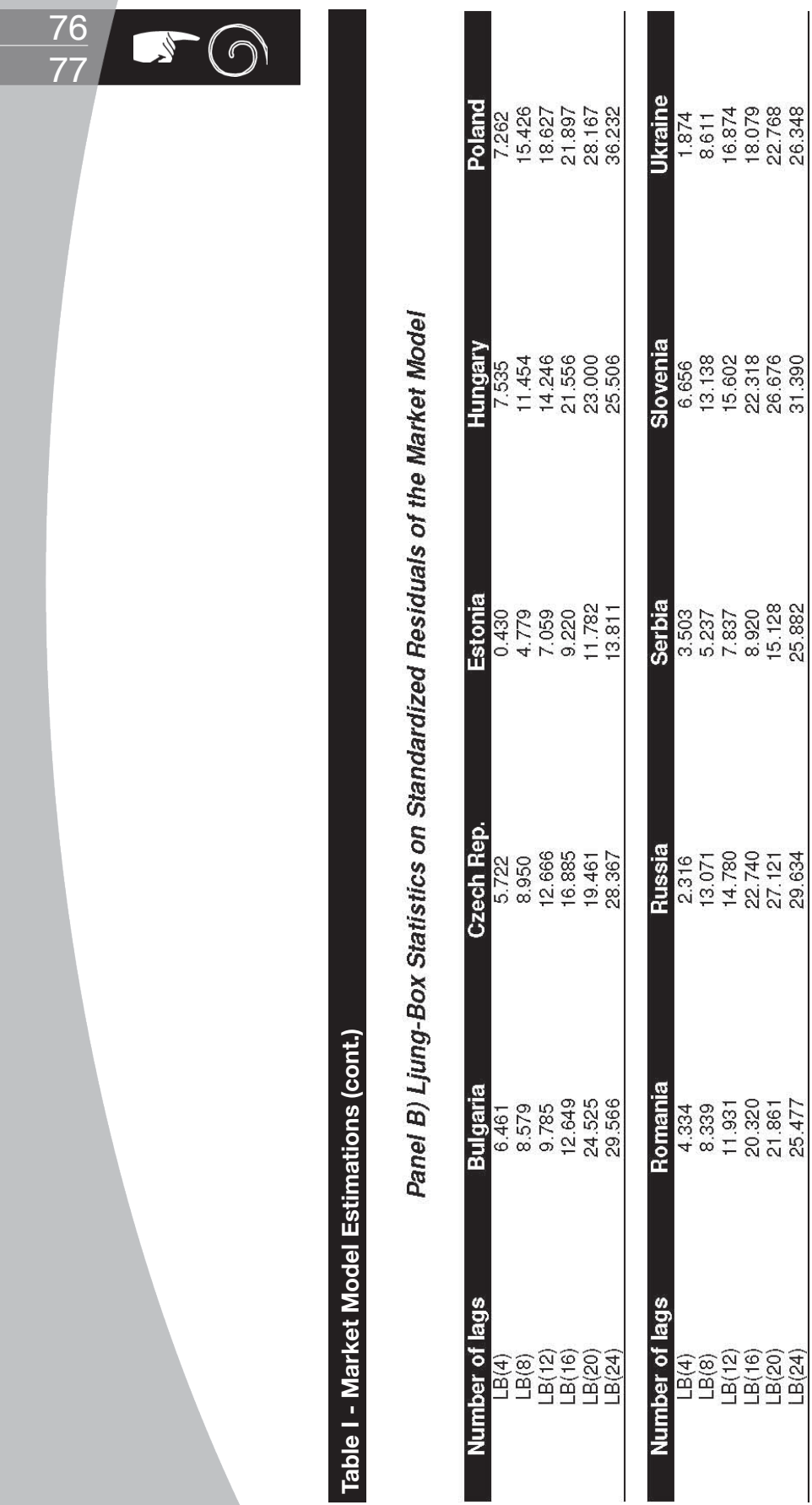

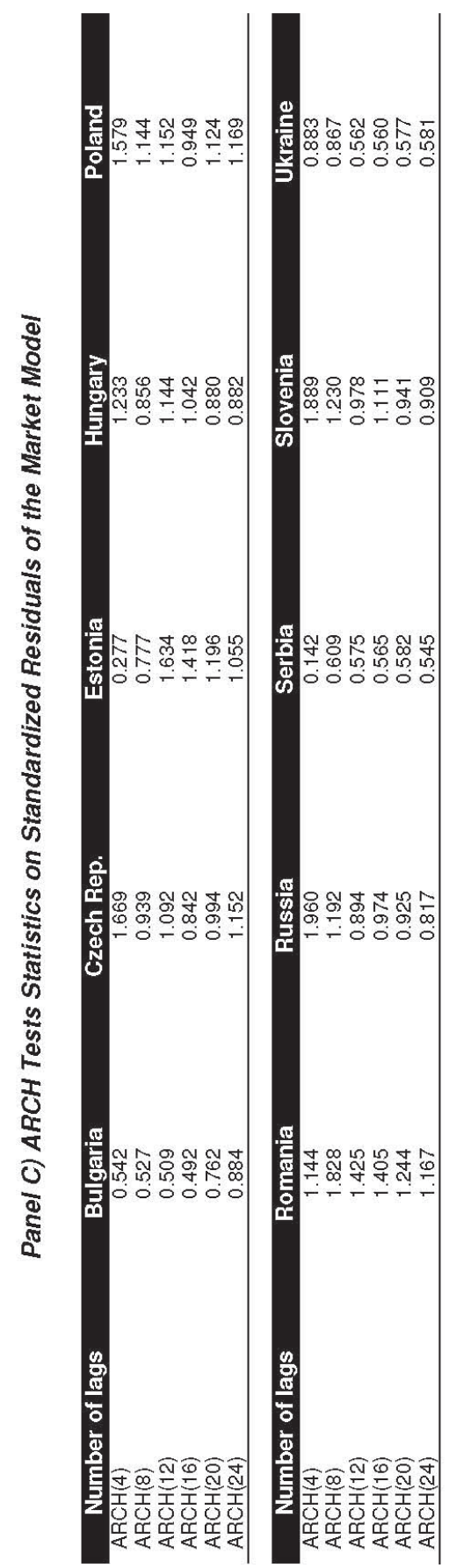


Table II shows the statistics of the time-varying betas, which include the mean, standarddeviation, minimum and maximum. The average of the betas mean is 1.1579. The domestic markets whose mean betas are closer to the average are Estonia, Serbia and Poland. The domestic markets with the mean betas more distant from the average are Hungary and Slovenia, which indicates a weak linkage between these two markets and the others. Additionally, several cases of negative betas calculated for Hungary and Slovenia, preclude the calculation of Treynor ratios for these two markets. Thus the stock indexes of Hungary and Slovenia are excluded from the Treynor ratios linkage analysis, presented in the following section.

\section{Table II - Basic Statistics on Time-Varying Betas}

\begin{tabular}{ccccc} 
& Mean & Std. Error & Min & Max \\
Bulgaria & 2.0928 & 0.0606 & 1.8233 & 2.4094 \\
Czech R. & 0.3137 & 0.0217 & 0.2058 & 0.4121 \\
Estonia & 1.1237 & 0.0146 & 1.0585 & 1.2017 \\
Hungary & 0.1531 & 0.0607 & -0.1565 & 0.4423 \\
Poland & 1.0544 & 0.0148 & 0.9824 & 1.1308 \\
Romania & 1.6824 & 0.0164 & 1.6058 & 1.7682 \\
Russia & 2.4352 & 0.0438 & 2.2310 & 2.6607 \\
Serbia & 1.2381 & 0.0283 & 1.0960 & 1.3649 \\
Slovenia & -0.4140 & 0.0260 & -0.5476 & -0.2935 \\
Ukraine & 1.8991 & 0.0422 & 1.7026 & 2.0977 \\
Average & 1.1579 & & & \\
\hline
\end{tabular}

\section{A Vector Autoregressive model on performance transmission between the different} domestic indexes

Some ex post excess returns have negative values, which produce negative ex post Treynor ratios. As shown by Fonseca (2013), ex post excess returns must be scaled to be non-negative, by adding a constant, to all of them, when Treynor ratios are used for the purpose of portfolio construction. This procedure was also used in the present article, by adding a constant term, c, to the ex post excess returns, before the calculation of ex post Treynor ratios. The value given to the constant is $\mathrm{c}=-\min \left(R_{i, t}-r_{f} t\right)$, which, taking into consideration that $\min \left(R_{i, t}-r_{f} t\right)<0$, ensures that positive values are calculated for the Treynor ratios. Thus, the final formula for the modified Treynor ratios, whose basic statistics are presented in Table III, becomes:

$T_{i, t}=\frac{R_{i, t}-r_{f, t}+c}{\beta_{i, t}}$

The basic statistics of the Treynor ratios show that the stock markets whose Treynor ratios mean is closer to the sample average are Estonia, Poland and Serbia. 


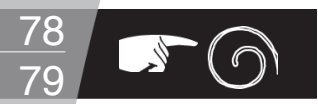

\begin{tabular}{ccccc}
\multicolumn{5}{c}{ Table III - Basic Statistics on the Modified Treynor Ratios } \\
\hline & Mean & Std. Error & Min & Max \\
Bulgaria & 0.1363 & 0.0093 & 0.0682 & 0.1776 \\
Czech R. & 0.9119 & 0.0477 & 0.7444 & 1.1763 \\
Estonia & 0.2548 & 0.0178 & 0.1705 & 0.3883 \\
Poland & 0.2710 & 0.0166 & 0.1880 & 0.3491 \\
Romania & 0.1699 & 0.0142 & 0.0000 & 0.2421 \\
Russia & 0.1177 & 0.0101 & 0.0747 & 0.1660 \\
Serbia & 0.2308 & 0.0184 & 0.1457 & 0.3509 \\
Ukraine & 0.1503 & 0.0130 & 0.0931 & 0.2182 \\
Average & 0.2803 & & & \\
\hline
\end{tabular}

The performance transmission between these eight markets was estimated by a VAR model, modified to include leads. The lags influence on the variables current values, designated in literature by Granger causality, depends on observed past data. By the contrary, the leads influence on the variables current values, designated in literature by Sims causality, depends on the forecast capability of the markets participants, which is more limited than their ability to follow past information. Thus, the estimated VAR has the following general representation:

$\left[T R_{t}\right]=A_{0}+\sum_{i=1}^{I} A_{i}\left[T R_{t+i}\right]+\sum_{j=1}^{J} A_{j}\left[T R_{t-j}\right]+\left[\varepsilon_{t}\right]$

where $\left[\mathrm{TR}_{t}\right]$ is a vector of current values of the Treynor ratios (each value refers to one domestic stock market), $A_{o}$ is the constant terms vector, $A_{i}$ and $A_{j}$ are parameters matrices, $\left[\mathrm{TR}_{t+j}\right]$ is a vector of lead values of the Treynor ratios, $I$ is the VAR lead-length, $\left[\operatorname{TR}_{t-j}\right]$ is a vector of lag values of the Treynor ratios, $J$ is the VAR lag-length model, and $\left[\varepsilon_{t}\right]$ is the vector of error terms. The determination of the VAR lag-length, and the VAR lead-length was based on the calculation of the Akaike Information Criteria (AIC) and the Schwarz Bayesian Criteria (SBC), which are defined, respectively, as follows:

$$
\begin{aligned}
& A I C=T \log |\Sigma|+2 N \\
& S B C=T \log |\Sigma|+N \log (T)
\end{aligned}
$$

where $T$ is the number of usable observations, $|\Sigma|$ is the determinant of the variance/ covariance matrix of the residuals, and $\mathrm{N}$ is the total number of parameters estimated in all equations. The determination of the VAR lead and lags lengths was done in two separate steps. In the first step, the number of leads was fixed to be equal to one, and the AIC and SBC statistics were calculated for five different lags, $i=1, \ldots, 5$. The lag-length was chosen according to statistics results in the first step, and it was used as a fixed value in the second step, in which the AIC and SBC statistics were calculated for five different leads, $j=1, \ldots, 5$. The results of the calculation of the AIC and SBC statistics are shown in the Table IV. 
Table IV - AIC and SBC Statistics on the Treynor Ratios VAR Model

Panel A) Lag-length determination (lag-length =1)

\begin{tabular}{ccc} 
Lag & AIC & SBC \\
1 & -72310.5046 & -71637.8467 \\
2 & -72215.3788 & -71226.3686 \\
3 & -72341.5280 & -71036.2889 \\
4 & -72222.7958 & -70601.4517 \\
5 & -72136.1021 & -70198.7767 \\
\hline
\end{tabular}

Panel B) Lead-length determination (lead-length =3)

\begin{tabular}{ccc} 
Lead & AIC & SBC \\
1 & -72341.5280 & -71036.2889 \\
2 & -72229.6907 & -70608.3466 \\
3 & -72116.2777 & -71036.2889 \\
4 & -71980.0822 & -69726.8996 \\
5 & -71867.1011 & -69298.1854 \\
\hline
\end{tabular}

According to the results shown in Table IV- Panel A) the AIC statistic indicates that the VAR laglength is of 3 lags, while the SBC statistic indicates a VAR lag-length of 1 lag. The 3 lag-length was chosen to be included in the lead-length calculations. The results of these calculations, reported in Panel B, show that AIC and SBC statistics converge to a 1 lead-length. Taking into consideration the AIC and SBC results, the Treynor ratios VAR model used in the causality tests includes 3 lags and 1 lead. The results of causality tests, given by the F statistics of the VAR model estimations, are shown in Table V - Panel A) for Granger causality and in Table V - Panel B) for Sims causality. According to the statistics significant at the 1\%, 5\% and $10 \%$ levels, the dominant market, in Granger causality, is the Polish stock market, whose lagged Treynor ratios influence the performance of five other markets. This stock market is followed by the Czech, Romanian and Serbian stock markets which have Granger causality on three other stock markets. No significant Granger causality is put in evidence from the stock markets of Bulgaria, Estonia, Russia and Ukraine. The results on Sims causality, presented in Panel B, which are significant at the $1 \%, 5 \%$ and $10 \%$ levels, provide evidence that the influence of the forward performance of each market on the other is of five cases, from Czech Republic and Ukraine, four cases from Serbia, three cases from Bulgaria and Estonia, two cases from Romania and one case from Poland and Russia. 


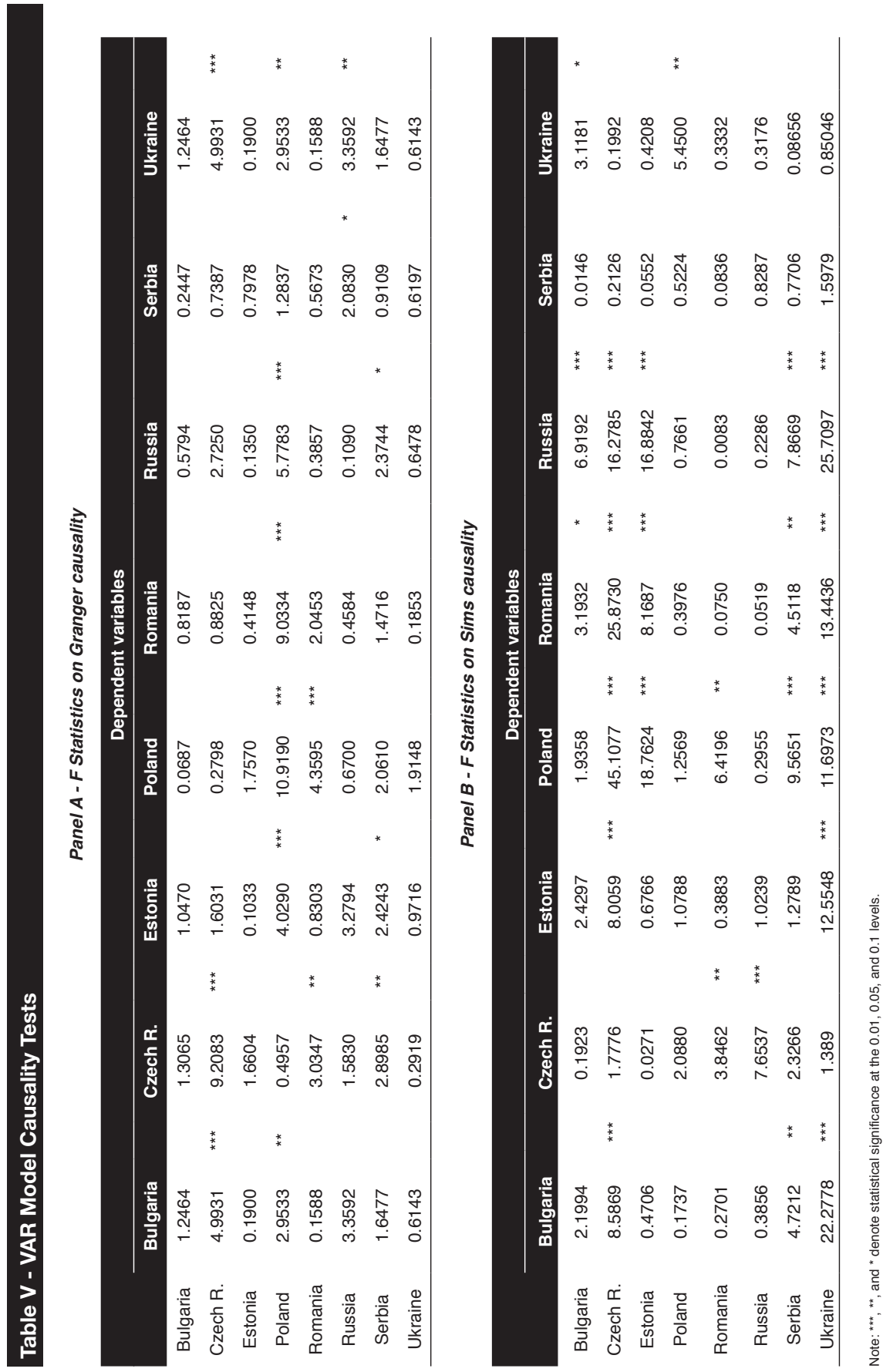


The present article studies the linkages between the Eastern Europe stock markets of Bulgaria, Czech Republic, Estonia, Hungary, Poland, Romania, Russia, Serbia, Slovenia and Ukraine. A regional index was constructed to estimate market models, using an approach with beta parameters depending on predetermined information variables. The markets whose beta values are closer to the whole sample average are Serbia, Estonia and Poland. On the opposite situation are Hungary and Slovenia, with beta values distant from the whole sample average, which indicates a weak linkage between these two markets and the others. Additionally, the market model estimation for Hungary and Slovenia produced several cases of negative betas which preclude their inclusion in the comparative performance analysis. The estimation of the market models was followed by the analysis of the performance causality between these stock markets, through the estimation of a VAR model on their Treynor ratios. The causality tests, supported by the VAR estimation, provided a clear evidence of the reciprocal performance influence across the majority of these markets, both in terms of Granger causality and Sims causality.

\section{References}

Adcock, C. (2007) Measuring portfolio performance using a modified measure of risk, Journal of Asset Management, 7, 388-403.

Adcock, C.; Cortez, M.C.; Armada, M.R.; Silva, F. (2012) Time varying betas and the unconditional distribution of asset returns, Quantitative Finance, 12(6), 951-967.

Bekaert, G.; Harvey, C. (1995) Time-Varying World Integration, Journal of Finance, 50(2), 403-444.

Fama, E.; French, K. (1992) The Cross-section of expected returns, Journal of Finance, 47(2), 427-465.

Fonseca, J.S. (2013) Innovations in return transmission and performance comparison between the five biggest Euro area stock markets, International Economics and Economic Policy, 10(3), 393-404.

Harvey, C. (1991) The World Price of Covariance Risk, Journal of Finance, 46(1), 111-157.

Huang, W. (2011) Financial integration and the price of world covariance risk: Large-vs. Small cap stocks, Journal of International Money and Finance, 26(8), 1311-1337.

Jagannathan, R.; Wang, Z. (1996) The conditional CAPM and the cross-section of expected returns, Journal of Finance, 51(1), 3-53.

Solnik, B. (1974) An Equilibrium Model of International Capital Market, Journal of Economic Theory, 8, 500-524.

Treynor, J. (1965) How to rate management investment funds, Harvard Business Review, 43(1), 63-75.

Treynor, J.; Mazuy, M. (1966) Can Mutual Funds Outguess the Market?, Harvard Business Review, 44(4), 131-136. 